2003

\title{
The UK's Climate Change Levy: Is It Working?
}

Benjamin J. Richardson

Osgoode Hall Law School of York University

Kiri L. Chanwai

Source Publication:

Journal of Environmental Law. Volume 15, Number 1 (2003), p. 39-58.

Follow this and additional works at: https://digitalcommons.osgoode.yorku.ca/scholarly_works cc) (1) $\Theta(9$

This work is licensed under a Creative Commons Attribution-Noncommercial-No Derivative Works 4.0 License.

\section{Recommended Citation}

Richardson, Benjamin J., and Kiri L. Chanwai. "The UK's Climate Change Levy: Is It Working?." Journal of Environmental Law 15.1 (2003): 39-58.

This Article is brought to you for free and open access by the Faculty Scholarship at Osgoode Digital Commons. It has been accepted for inclusion in Articles \& Book Chapters by an authorized administrator of Osgoode Digital Commons. 


\title{
THE UK'S CLIMATE CHANGE LEVY: IS IT WORKING?
}

\author{
Benjamin J. Richardson* and Kiri L. Chanwai $†$
}

\section{Introduction}

Is the UK government's Climate Change Levy (CCL) influencing British companies to become more energy efficient and to use clean renewable energy sources? This Article reviews briefly the arguments for using energy taxes in environmental policy. It explains the structure and operation of the CCL designed to reduce consumption of fossil fuels. The Article examines the CCL's implementation and considers the results of several empirical studies including a survey undertaken by Chanwai of the response of businesses in the Northwest of England. Finally, the Article proposes ways to redesign the CCL to enable it to more effectively support environmental goals.

In recent years, energy activities have surfaced from the relative backwaters of UK environmental regulation to occupy a central policy-making concern. The reason is climate change. As the scientific prognosis of global warming has firmed, and evidence of the likely economic and ecological ramifications become better understood, authorities in the UK and abroad have sought new instruments to control rising greenhouse gas (GHG) emissions. Carbon dioxide $\left(\mathrm{CO}_{2}\right)$ is the main culprit, accounting for over three-quarters of Britain's relevant emissions. ${ }^{1}$ The government's Climate Change Programme launched in November $2000^{2}$ and coordinated by the Department for Environment, Food and Rural Affairs (DEFRA), sketches how the UK intends to meet its Kyoto Protocol commitment of a $12.5 \%$ reduction on 1990 levels of all GHGs by 2012, and achievement of the separate domestic goal of a $20 \%$ cut in $\mathrm{CO}_{2}$ emissions below 1990 levels by 2010 .

Electricity generation is a major source of GHG emissions. The UK's electricity 
consumption jumped by $16 \%$ from 1990 to 1999 , although actual $\mathrm{CO}_{2}$ emissions declined because of the 'dash for gas' and improved performance of nuclear generation. ${ }^{3}$ The switch to gas, however, was a fortuitous event, and the government has conceded: 'the UK's energy sector is still largely reliant on fossil fuels and, unless they can be replaced by plants with low or no emissions, this dependence will increase after 2010 as existing nuclear power stations reach the end of their licensed lifetimes'. ${ }^{4}$ The Royal Commission on Environmental Pollution (RCEP) has advised that $\mathrm{CO}_{2}$ reductions of $60 \%$ by 2050 are necessary if Britain is to avoid dangerous climate change..$^{5}$ The Kyoto targets simply reflect what was politically feasible at the time and not what is appropriate from an ecological standpoint. ${ }^{6}$

The thrust of the government's plan to promote energy efficiency and expand the role of renewables is to change corporate behaviour through economic instruments. ${ }^{7}$ The key policy tools are the CCL, a Carbon Emissions Trading System (CETS), and a structure for trading in renewable energy supply obligations. The CETS is an experimental, voluntary regime and, like the tradeable 'Renewables Obligations', only very recently came into effect, making analysis somewhat premature at this stage. So far, the CCL is the government's primary weapon for tackling fossil fuel emissions. The Levy focuses on the industry sector, although it accounts for a minority of Britain's GHG emissions: transport is the biggest scourge, accounting for some $34 \%$ of final energy use, followed by households (29\%) industry and services (23\%) and agriculture $(14 \%){ }^{8}$ The growing dependence on economic instruments as a means of energy policy is based on a number of assumptions about the effectiveness of such instruments.

\section{Environmental Taxation}

\subsection{Development of Eco-Taxes}

In many jurisdictions, including the UK, economic instruments have become an increasingly fashionable environmental policy tool. ${ }^{9}$ During the 1990 s several 
European Union (EU) states, particularly in Scandinavia, introduced carbon and energy taxes to control GHG emissions, ${ }^{10}$ although the European Commission's proposal for a EU-wide tax failed to garner sufficient support, primarily because of international trade competition concerns given the absence of such a tax in the United States. ${ }^{11}$ Although 'eco-tax' proposals in the mid-1990s were grounded in Australia ${ }^{12}$ and the United States, ${ }^{13}$ recently some governments have become more tolerant of environmental taxation, such as New Zealand, which in April 2002 announced plans for a new carbon charge..$^{14}$ Nonetheless, eco-taxation remains often controversial; for instance, in December 2000 the French Constitutional Court nullified the government's extension of the pollution tax to consumption of fossil fuels and electricity. ${ }^{15}$ Two decades of market deregulation in the West has left energy and environmental taxes in many countries at levels relatively lower than they were 20 years ago. ${ }^{16}$

Although the UK has been wedded to planning controls and licensing for managing environmental pressure, as early as 1992 the government proclaimed, 'in future there will be a general presumption in favour of economic instruments'. ${ }^{17}$ Subsequently, the government introduced the landfill tax (1996) and amended company car taxation (2000), but abandoned plans for a pesticides tax..$^{18}$ The 1999 Sustainable Development Strategy promised: 'the Government will explore the scope for using economic instruments, such as taxes and charges, to deliver more sustainable development. Such measures can promote change, innovation and efficiency, and higher environmental standards'. ${ }^{19}$ The Treasury's 1997 Statement of Intent on Environmental Taxation posited key principles for the design of taxation reforms, beginning with that 'polluters should face the true costs which their actions impose on society'. However, the government's rhapsody for economic instruments has been tempered by the realisation that market tools can have unwelcome social and economic side-effects. The Treasury's Statement acknowledged that the polluter pays principle should be subject to several qualifications, including, that: 'the social consequences of environmental taxation must be acceptable'; and 'environmental 
policies must not threaten the competitiveness of UK business'.

The genesis of the CCL can be found in academic and policy studies dating from the 1960s. There exists a plethora of literature on the potential of taxes (and other economic instruments) to contribute to more efficient and more effective environmental policy. ${ }^{20}$ Compared to traditional command regulation involving technology or emissions licensing standards, eco-taxes and tradeable emission allowances may enable society to achieve a given environmental outcome at a lower economic cost, or achieve a superior environmental outcome at the same cost. ${ }^{21}$ Interest in economic approaches to environmental regulation arose among academic circles in the 1960s, influenced by the pioneering theories of Pigou and Coase. ${ }^{22}$ In the 1970s, the Organisation for Economic Cooperation and Development (OECD) advanced the concept of the 'polluter pays' principle (PPP) as a basis for removing hidden subsidies that gave an unfair competitive advantage to polluting industries. ${ }^{23}$ In the $1980 \mathrm{~s}$ and $1990 \mathrm{~s}$, under the influence of the sustainable development discourse, the PPP was repackaged into the more broad-based 'internationalisation of environmental costs' principle. ${ }^{24}$ The EU Treaty was amended to provide that 'the polluter should pay' principle be a basis of Community policy on the environment. ${ }^{25}$

A number of Scandinavian and other European countries have adopted energy taxes (Denmark, Finland, Germany, Italy, the Netherlands, Norway and Sweden). ${ }^{26}$ These have often taken the form of extended systems of fuel excises in which rates of tax are defined for each fuel with regard to fuel quantity and approximation of carbon content (see Sweden, Norway, Finland, the Netherlands, and Denmark). Further, the level of tax can vary according to the type of energy user; in Sweden and the Netherlands, much lower rates of tax apply to industrial energy users than to electricity consumed by private households. Although the highest taxes have been adopted by Denmark, Norway, and Sweden, some existing energy taxes were reduced at the time of the new taxes and all three countries offer substantial tax relief to industry. On the other hand, the smaller energy taxes 
imposed by Finland and the Netherlands make fewer concessions to industry. Significantly, none of the above five countries has significant domestic coal production, and several derive most of their electricity from hydropower. Consequently, international competitiveness concerns would not have weighed as heavily in these countries as they have in Australia or the United States. ${ }^{27}$

\subsection{Theoretical Perspectives on Eco-Taxes}

From the standpoint of environmental policy, eco-taxes may be attractive for several reasons. ${ }^{28}$ Firstly, eco-taxes can promote efficiency gains through reallocation of pollution (e.g. carbon) abatement costs and through performance incentives. The costs of pollution reduction typically vary among firms (known as different 'marginal costs of abatement'), and efficient businesses should seek to lower their tax burden by investing in clean production technologies where this is most cost effective. ${ }^{29}$ Other policy instruments such as pollution licenses cannot be readily tailored to reflect each polluter's abatement or energy management costs. ${ }^{30}$ Secondly, eco-taxes provide innovation incentives; they can give polluters an ongoing incentive to seek more efficient ways (e.g. technological innovations or recycling) to reduce emissions or save energy, whereas there is little financial incentive to do better once prescribed environmental standards are met. ${ }^{31}$ Thirdly, eco-taxes should be less vulnerable to regulatory capture compared to command regulation; where regulators attempt to set differentiated company-by-company targets they must acquire the necessary information about each firm's abatement or technology characteristics, which creates a risk for regulators of getting drawn into negotiations and the making of concessions to industry as a price for their cooperation. $^{32}$ Eco-taxes can take account of all businesses' differing pollution abatement costs without the need to consider the particular circumstances of individual firms. Fourthly, eco-taxes can also generate substantial revenues that can be recycled for environmental improvement investments. However, the revenue of an eco-tax is coincidental, and should decrease where a tax is 'ecologically optimal' $^{33}$ 
Apart from the environmental benefits, eco-taxes may yield economic and political advantages. When eco-taxes are introduced as part of systematic revision of a nation's tax system, with corresponding reductions in income and employment taxes-known in the literature as 'ecological tax reform' - there may also arise the benefits of jobs growth and economic investment (the 'double dividend' hypothesis). ${ }^{34}$ Secondly, it has been argued that using taxes and other economic instruments has democratic benefits in that enables the public to focus on the fundamental questions of what level of pollution at what cost is socially desirable rather than obfuscate such issues when the public is expected to focus on the minutiae of pollution licensing. ${ }^{35}$

Eco-taxes, along with other economic instruments, are not however without potentially significant limitations. Unlike quantitative pollution regulation (or tradeable emission permits operating within a pollution cap), eco-taxes suffer from the drawback that they have uncertain environmental effects. The level of pollution reduction engendered flows from companies' responses to the financial incentive of the tax, and it is difficult to model in advance what level of taxation is necessary to provoke a particular environmental effect. ${ }^{36}$ Secondly, in large decentralised companies with specialised branches, decisions made by responsible units regarding desired pollution abatement or energy saving efforts in response to eco-taxes may not be effectively imparted to all arms of the business. Large firms may also be preoccupied with other priorities, causing them to disregard small environmental taxes as just another business cost. Thirdly, eco-taxes and other economic instruments usually require significant re-regulation to ensure their proper functioning and enforcement. Economic instruments do not necessarily mean costreducing market deregulation, and arrangements for monitoring and enforcing economic instruments can be complex and expensive ${ }^{37}$ Fourthly, in the absence of international environmental tax harmonisation, eco-taxes levied on one country's industry may also damage that country competitively by making foreign imports relatively cheaper if competitor countries have no similar taxes..$^{38}$ Some existing academic research however suggests that such fears may be exaggerated. ${ }^{39}$ Fifthly, 
eco-taxes can collide with social policy concerns, primarily when the poor are disproportionately affected because a larger share of their income is spent on taxed items such as heating or lighting fuel. ${ }^{40}$ Compensatory payments can be made, although this increases administrative complexity. And finally, arguments have been made by Sagoff and others that using market-based policy mechanisms wrongly bases environmental decisions on people's 'consumer' preferences rather, as they assert should be the case, people's 'citizen' preferences given the political and ethical issues at stake. ${ }^{41}$

On balance, there would appear to be a role for eco-taxes and other economic instruments as a means of environmental policy, but that the justification for using eco-taxes depends on the specific environmental problem and the prevailing market and institutional characteristics. Environmental policy-makers cannot rely on economic instruments to make fundamental judgements about environmental strategy: overall environmental quality objectives should be democratically determined by government, such as sustainable $\mathrm{CO}_{2}$ loads in the atmosphere. ${ }^{42}$ Successful applications of eco-taxes hinge on careful design and implementation-there is a considerable jump from theoretical principles to effective practical applications. Problems may arise if tax structures are too complex (hence costly to administer) or if tax incentives are insufficiently large to spur changes in firms' or individuals' behaviour. The political feasibility of new ecotaxes must also be addressed at this stage. ${ }^{43}$ Eco-taxes are likely to be most valuable, suggests Smith, 'where wide-ranging changes in behaviour are needed across a large number of production and consumption activities'. ${ }^{44}$ In such circumstances, the alternative of direct source-by-source regulation would likely generate unacceptable high costs. However, it is important to recognise that rarely is it a dichotomous choice between economic instruments and command regulation.

Grabosky and Gunningham remind us that: 'single instrument ... approaches are misguided ... [and] that in the large majority of circumstances (though certainly not all), a mix of instruments is required, tailored to specific policy goals' ${ }^{45}$ Solutions to 
climate change and sustainable energy use in particular entail numerous economic sectors and actors, each of which needs a combination of policy instruments.

\section{The Climate Change Levy}

\subsection{Development of the Levy and its Structure}

In his March 1998 Budget, the Chancellor announced a review into the suitability of a tax on the industrial and commercial use of energy. ${ }^{46}$ The resulting Lord Marshall report recommended that both taxation and tradeable emission permits could assist the UK to reduce its GHG emissions, but it favoured an early introduction of a compulsory energy tax, coupled with a pilot tradeable emissions scheme pending further investigation of this option until international trading formally began. ${ }^{47}$ Lord Marshall favoured a tax based on energy consumption (excluding renewables) rather than the carbon content of fuels, partly because of difficulties measuring the equivalent $\mathrm{CO}_{2}$ content of electricity generated from various primary fuels. ${ }^{48}$ Marshall also cautioned that an energy tax should not be imposed on the domestic sector (due to fuel poverty concerns) and that 'any measures must be subject to careful design in order to protect the competitiveness of British industry and maximise their environmental benefit'. ${ }^{49}$

Plans for the CCL, which were mooted in the Chancellor's March 1999 Budget, $^{50}$ generally followed the recommendations of Lord Marshall. ${ }^{51}$ The energy intensive chemical and steel industries were among the most critical of the CCL proposal, ${ }^{52}$ predicting a disproportionate burden on manufacturing and adverse international competitiveness effects. ${ }^{53}$ But many businesses consulted accepted a role for energy taxation; the Advisory Committee on Business and the Environment favoured a longterm policy framework within which UK businesses could deliver carbon savings costeffectively without harm to business competitiveness. ${ }^{54}$ Following two years of consultation, ${ }^{55}$ the Levy was adjusted with inclusion of some additional financial concessions, as outlined below, which appeared to be broadly acceptable to industry ${ }^{56}$ The structure of the Levy also proved to be acceptable to the European 
Commission's Competition Directorate. ${ }^{57}$

The CCL was introduced as a 'downstream' energy tax based primarily on industrial use of energy rather than an 'upstream' carbon tax on energy suppliers. Implemented through Schedule 6 of the Finance Act 2000 and collected by HM Customs and Excise, the Levy applies to energy used by industry and the public sector, but not to energy consumed in households, transportation or registered charities. Also exempt are small businesses using limited amounts of energy equivalent to 'domestic use'. Further, horticulturist businesses, recognised by the government as a 'special case' high-energy user, enjoy a 50\% discount for up to five years. Not all fuels are taxed; renewable energy (with the exception of large scale hydropower greater than $10 \mathrm{MW}$ ) is exempt so as to encourage businesses to opt for non-fossil fuels. Suppliers of exempt renewable energies must hold a Levy Exemption Certificate, issued by the Office of the Gas and Electricity Markets. Also exempt is approved combined heat and power (CHP), which is a recycled lowcarbon energy form, fuels used as a feedstock, and electricity harnessed in electrolysis processes (e.g. in aluminium smelting). Electricity from nuclear power, although not a fossil fuel, is subject to the CCL- arguably an appropriate measure given that nuclear power poses its own environmental problems and to exempt nuclear energy would have encouraged more investment in this sector at the expense of the fledgling renewables market. The CCL does not apply to oils already subject to excise duties. The current CCL rates include $0.15 \mathrm{p} / \mathrm{kWh}$ for gas, coal and coke, and $0.43 \mathrm{p} / \mathrm{kWh}$ for electricity, and the Levy is set to rise year-onyear, although no rise was made on its 2002 anniversary. The CCL is added to energy consumers' bills before VAT and has increased on average by $15 \%$ the energy bills of businesses.

\subsection{Levy Concessions}

The CCL was advanced on a fiscally revenue neutral basis at a macroscopic level, although not necessarily revenue neutral at the level of individual firms, through a $0.3 \%$ reduction in all employers' national insurance contributions (NICs). Such a 
financial design reflects principles of ecological tax reform. The latter has been defined as 'shifting taxation off the value-adding activities of people (employment, enterprise and investment) onto the value-subtracting use of energy and resources and associated creation of wastes and pollution, ${ }^{58}$ It is an approach endorsed by the UK's Sustainable Development Strategy $1999,{ }^{59}$ and the European Commission. ${ }^{60}$ The German government has gone the furthest in ecological tax reform: ${ }^{61}$ under the 1999 Law Initiating the Ecological Tax Reform, higher energy taxes were offset by reductions in workers' and employers' social security contributions. ${ }^{62}$

The CCL's financial impact is further assuaged by the enhanced capital allowances (ECAs) scheme, whereby investment in specific energy efficient products (e.g. pipework insulation and thermal screens) enables companies to reclaim $100 \%$ of the capital allowance in the first year. The ECAs are administered by the Carbon Trust, established in April 2001 as an independent, non profit-making company to recycle some $£ 150$ million of CCL receipts over three years to quicken the adoption of low carbon technologies. ${ }^{63}$ The Trust's remit extends to provision of advice and information, research and demonstration projects.

The main way energy intensive companies can manage their tax liability and improve environmental performance is through participation in the Climate Change Agreements (CC Agreements). An up to $80 \%$ discount from the Levy is available to companies that pursue challenging targets for improving energy efficiency or reducing carbon emissions through agreements negotiated between their relevant sector trade associations and the Secretary of State. The scheme is restricted to 'energy intensive' industries, as defined in Parts A1 and A2 of Schedule 1 of the Pollution Prevention and Control (England and Wales) Regulations 2000.64 The agreements operate until 31 March 2013. To date, umbrella agreements with 44 trade associations have been concluded, each association covering a plethora of individual businesses and some 8,000 industrial sites in all. Participants include the Brewers and Licensed Retailers Association; British Cement Association; 
Society of Motor Manufacturers and Traders Ltd; Food and Drink Federation; and British Apparel and Textiles Confederation. ${ }^{65}$

The CC Agreements do not dictate how companies must achieve energy reduction and efficiency performance targets; rather, they detail the goals and methods for calculating performance, and reporting and verification protocols ${ }^{66}$ Each sector has a target and a set of two-yearly milestones when performance is reviewed. Failure to meet agreed targets results in the Levy rebates being suspended or withdrawn. Parties that exceed their targets may trade their 'credits' with other businesses through the CETS, and may purchase allowances if necessary to meet target shortfalls. The Agreements are subject to five-yearly reviews and possible adjustments as a result of each review.

\section{Implementation of the Levy}

Implementation of the CCL can be evaluated against a variety of criteria, and the most important ones are economic impacts and environmental effects. On the environmental criterion, DEFRA estimated that the CCL package (including the CC Agreements) would save $5 \mathrm{MtCe}$ (million tonnes of $\mathrm{CO}_{2}$ equivalent) per year by 2010. ${ }^{67}$ It appears $\mathrm{CO}_{2}$ emissions actually rose by $1.5 \%$ in 2001 , supposedly due to more coal usage in power stations in response to higher gas prices. ${ }^{68}$ The Energy Minister, Brian Wilson, admitted in May 2002 that it appeared unlikely that Britain would reach its stepping-stone target of $5 \%$ of electricity generated from renewables by end of $2003 \cdot{ }^{69}$ It is an altogether different but vital question, of course, whether such emission reduction and renewable energy targets are sufficient to avoid dangerous climate change.

In terms of economic impacts—crucial to the political viability of the CCL—various commentators and industry groups made dire forecasts of the Levy's impact on the private sector. A sensational report by Business Strategies (sponsored by steel, chemical and engineering industry associations), predicted the CCL would provoke 156,000 job losses over ten years, reduce UK manufacturing productivity 
by $0.8 \%$ and generally weaken UK international trade competitiveness. ${ }^{70}$ Various trade and industry periodicals carried similar alarmist predictions. ${ }^{71}$ As many UK companies had already supposedly made great strides in improving their energy and materials efficiency in order to stay in business, it was believed that the Levy would bankrupt many such firms at the margins of solvency. ${ }^{72} \mathrm{~A}$ contrasting view came from a study commissioned by the UK Worldwide Fund for Nature, which found that industries employing 93\% of the UK workforce would either benefit from the CCL package or incur only a very slight net cost. ${ }^{73}$ It also pointed out that given recent falls in electricity prices, the CCL would merely restore such fuel prices to their levels of five years ago.

Other studies highlighted possible regional and sector specific effects. The construction industry, services sector and the public sector would be net winners as they are relatively labour-intensive (thus benefiting from the NIC reductions) than energy-intensive. The chemical, plastics and steel industries are among industry sectors commentators predicted would be maligned by the CCL because of their high-energy needs and low staffing. ${ }^{74}$ However, such differences do not seem to account for the fact that energy intensive industries are eligible to receive an 80\% CCL rebate by participating in the CC Agreements. Apart from differential economic sector effects, there are also possible geographical variations in the impact of the CCL; Business Strategies predicted such regional disparities, with northern British manufacturers to be disproportionately affected because of their higher concentration of energy intensive companies. ${ }^{75}$

Recently, evidence is emerging of the actual effects of the Levy. SGS Consulting surveyed 100 small and medium enterprises (SMEs) in early 2002 on their reaction to the CCL. ${ }^{76}$ It found that $25 \%$ of enterprises were unaware that the Levy had come into force, and that almost a quarter of firms did not understand the Levy's purpose or how its revenue was spent. Half of SME manufacturers reported that they believed the CCL would ultimately have a negative impact on their business against a quarter of respondents who believed that the Levy would have a net positive financial effect 
due to the NIC reductions. The SGS study found that $27 \%$ of SMEs had implemented a programme to monitor or manage their energy consumption, with installation of energy efficient lighting being the most popular method, although it was not clear whether such energy management measures were in direct response to the CCL. SGS Consulting suggested special measures were needed in the CCL package to directly assist SMEs because their size reduced their access to the CC Agreements or to Levy-exempt CHP fuels. ${ }^{77}$

A second, more detailed study, conducted by the Federation of Small Businesses ${ }^{78}$ found that $66 \%$ of SMEs were better off after the Levy due to the NIC reduction whilst remaining under the CCL exemption threshold because of their low energy usage..$^{79}$ Of the $34 \%$ of SMEs subject to the Levy, FSB concluded that $88 \%$ were financially worse off, with the main 'losers' being SMEs involved in plastics processing, hospitality and certain retailers. ${ }^{80}$ It gave as an example a plastic moulding company employing 35 staff that was unable to participate in a CC Agreement and incurred a net annual loss of $£ 6,875$ due to the CCL. ${ }^{81}$ The FSB study was critical of the additional membership costs of participating in the CC Agreements. ${ }^{82}$ A third, shorter survey, conducted by London Electricity of professionals working in the energy industry, revealed that $42 \%$ of respondents felt the CCL had caused a net increase in their business's costs and 33\% did not believe that the CCL had prompted new energy management initiatives. ${ }^{83}$ Sixty per cent of respondents agreed that more guidance was needed on how to obtain and utilise renewable energy.

Other insights into the Levy's effects are coming from trade associations, industry publications and academic commentators. Some instances of significant energy savings have been reported among engineering businesses in response to the CCL. ${ }^{84}$ Studies suggest that most organisations can reduce their energy bills by up to $10-20 \%$ through low or no cost measures. ${ }^{85}$ This can substantially offset the average $15 \%$ increase in the average industrial user's annual electricity bill caused by the Levy, without taking into account the effects of the NIC reductions and Levy rebates. On the other hand, some companies appear to have 
experienced lengthy delays (and costs) in joining the CC Agreements because of insufficient information on eligibility criteria provided by authorities. ${ }^{86}$

\section{Survey of Northwest Businesses}

From July-September 2002, Chanwai undertook an exploratory investigation and conducted questionnaires delivered by site visits, telephone and email, of three sample groups of businesses and organisations in the Northwest of England, regarding their experience with the CCL and ancillary energy policies. ${ }^{87}$ This region has a major share of the UK's heavy industry and thus would be expected to particularly affected by the CCL. The research was undertaken under the auspices of Sustainability Northwest in Manchester, which helped with choice of the survey samples and research logistics. The three samples were: an exploratory investigation of twelve major businesses and organisations involving interviews; a schedule list of questions delivered by telephone or site visit to six energy supply companies in the region; and a wider questionnaire survey of forty companies and organisations in the Northwest (the 'wider population'), in order to assess whether the key issues identified in the first core sample group were consistent with those of the larger business community. The first sample group included a local council, an airport operator, several heavy manufacturing and engineering companies, financial institutions, and several firms in the retail and service sector. ${ }^{88}$ The questions covered inter alia respondents' knowledge of the Levy; adoption of new energy management practices; the effects of the NIC reductions; and desired changes to the CCL regime. All respondents demonstrated some awareness of the workings of the Levy, ranging from a 'general awareness' to an 'in-depth knowledge'. Eleven of the twelve respondents already had in place policies and/or practices for energy efficiency and conservation prior to the Levy, including in several cases involving ISO 14001 registration. However, of the eleven businesses, four had not implemented additional energy management practices since the CCL and of those that had, five were doing so only because they were participating 
or applying to participate in a CC Agreement.

The research pointed to the importance of the CC Agreements process rather than the Levy per se in driving efforts to control GHG emissions. However, a couple of firms commented that they had found the CC Agreement process 'complex and costly', due to obligations to identify, calculate and report emissions (e.g. energy per unit per product), and concerns that expenditure on installing energy measuring equipment might exceed the final value of the CCL rebate. Energy management practices adopted by these and other companies included designation of staff as energy managers and new energy house-keeping programmes (e.g. low energy light bulbs and voltage monitoring). Interestingly, only two companies had acted to source more of their electricity from renewable energy sources, and the one business with an existing CHP plant (CCL exempt) only operated it at half capacity because of its high cost. Several companies reported that their large size impeded effective delivery of new energy efficiency initiatives to dispersed offices and branches. An important selling point of the Levy was the off-setting employers' NIC reductions, but none of the respondents disclosed any additional staff recruitment because of their lower payroll taxes. In two cases, firms admitted difficulties detecting and measuring any relationship between the financial effects of the Levy and the NIC changes because their energy budget and company payroll were managed by separate accounting systems.

In terms of possible changes to the CCL regime, some respondents requested more and clearer information from the government on how to reduce their Levy liability through energy conservation actions. One company felt although there had been a proliferation of energy advice schemes, the result had only been confusion not clarity. Other respondents mentioned it would be preferable to receive up-front public grants rather than tax-deduction capital allowances to spur new investment in clean energy technologies. It was also mentioned that the ECAs should be amended to subsidise the running costs of new energy efficient investments. A couple of companies also complained that the CCL scheme should be adjusted to recognise prior environmental 
and energy performance improvements made by affected companies, although it was unclear how this could be implemented.

The second sample surveyed six energy supply companies in terms of their reaction to the Levy (although it does not directly apply to them), and barriers they may have experienced to expanding CCL-exempt renewable energy generation. All the respondents professed a strong interest in expanding renewable energy supplies, although only two of the six cited increased consumer pressure for so doing. The main reason was the effect of the Renewables Obligation (RO). The RO was introduced through the Utilities Act 2000 (and took effect in 2002), obliging energy supply companies to increase their provision of renewable energy supply to $10.4 \%$ of total electricity supply by $2010 .^{89}$ All the respondents reported two distinct barriers to expanding their supply of renewables. These were connecting green fuel sources to the national electricity grid and planning legislation restrictions to new energy projects such as wind farms. In several cases, respondents reported intransigence or hostility from local councils to renewable energy projects. Difficulties in obtaining development consents under the Town and Country Planning Act 1990 reported by the respondents have also been cited in other studies. ${ }^{90}$ Regarding the electricity grid, several energy companies cited problems associated with the connection costs for new renewable energy supplies and, secondly, the difficulties of integrating small and intermittent electricity supplies to the New Electricity Trading Arrangements (NETA), introduced on 27 March 2001 as the framework for the wholesale electricity market in England and Wales. ${ }^{91}$ Under NETA, electricity suppliers and generators must contract directly with each other, and penalties are imposed where demand exceeds contracted levels or generation falls short of it. Through these market reforms, NETA sought to stimulate genuine competition into wholesale electricity trading and provide price reductions for consumers. But for small energy generators, whose supplies may be intermittent and less reliable, there is a danger of breaching contracted supply levels and so incurring heavy financial penalties. ${ }^{92}$ Due to the current price reductions from the NETA deregulation gas and electricity wholesale 
market, some respondents felt that certain renewable energy projects were not economically feasible, even apart from planning law and grid connection concerns.

From the wider population of 40 business and organisations in the Northwest of England sampled, ${ }^{93}$ the findings were broadly consistent with the trends from the core group. Regarding companies' knowledge of the workings of the CCL and how it affected their operations, $85 \%$ of respondents indicated a general awareness of the Levy, but were less knowledgeable of specific issues, such as who qualified as a 'high energy intensive' user (30\% of respondents) for the purpose of CC Agreement participation. Regarding the effects of the NIC reduction, $55 \%$ of the respondents reported no net financial benefit. This appeared to be due to the characteristics of business' operations and corporate structure, as well as reliance on separate accounting systems that obfuscate the relationship between energy bills and payroll taxes.

A high $82 \%$ of respondents from the wider population sample admitted to making some energy management changes to their business operations before the Levy, and $55 \%$ making changes after the Levy. Of both sets of changes, low cost, non-invasive measures were overwhelmingly favoured. Such a level of 'voluntary' action reflects practice in other jurisdictions such as Australia where the country's national greenhouse challenge programme has focused on encouraging businesses to adopt 'no regrets measures'-i.e. those that can be done profitably alone regardless of any additional environmental justification. ${ }^{94}$ Examples of measures adopted in the UK sample included subscription to voluntary environmental management systems (e.g. ISO 14001) and establishment of energy management teams.

Changes made by respondents after the Levy showed a relative decrease in implementation of positive pro-action measures. Public organisations (e.g. local councils) showed a generally stronger commitment to invest in energy management measures than companies. Thirty per cent of respondents reported making 'no' changes in response to the CCL, compared to the $17 \%$ who made 'no' changes 
before the Levy. Of the companies and organisations making further energy management changes in response to the CCL, an increasing proportion of these changes were low cost rather than high cost measures. Some respondents indicated that the existence of preexisting energy conservation measures made additional changes superfluous (e.g. continuation of ISO 14001 accreditation). Overall, this may infer that companies and organisations are currently restrained by financial resources from implementing seemingly expensive reforms or that firms are currently focusing on picking the easy low hanging fruit (i.e. adopting 'no cost' actions) and postponing the costly measures. In responding to the CCL, the primary challenges reported by respondents related to time and labour resource constraints. Some firms faced what were perceived as more pressing corporate priorities, and in any event indicated (42\% of respondents) difficulties in disseminating new corporate energy policies and practices among their decentralised offices and branches. Given the prevalence of subsidiaries and franchise networks in modern corporate structures, it would seem that government environmental reforms should be increasingly sensitive to the form of corporate governance. ${ }^{95}$ Financial resources were also identified as a 'challenge' by $45 \%$ of the respondents, especially in relation to small firms. Fifty per cent of respondents stressed challenges related to inadequate media and government information on the Levy and the problem of accessing affordable renewable energy sources. Another challenge identified ( $40 \%$ of respondents) concerned the complexities of joining the CC Agreements scheme-some saw it as too technical to facilitate wider interest.

A minority of respondents (17\%) reported 'no challenges' in adapting to the Levy, perhaps inferring that some companies are simply uninterested in reducing an extra cost to their operations, or lack awareness of the connection between GHG emissions and corporate profitability. It also raises the fundamental question whether the CCL rate is too low and that the price differential between green and brown fuel is insufficient to influence polluters. Ways to improve the CCL regime mentioned by the wider population were consistent with the findings from the core sample. The 
following section explores how the CCL might be redesigned in the light of this and other research.

\section{Reforming Energy Taxation}

\subsection{Redesigning the Climate Change Levy}

The use of energy pricing mechanisms to address GHG emissions appears set to remain an indelible feature of UK environmental regulation, and there are good reasons that this should be so. Even critics of the CCL, such as the Confederation of British Industry (CBI), have conceded that eco-taxes can when well designed produce positive environmental and economic results. ${ }^{96}$ The problem, however, is that environmental taxes do not always translate well into effective design. The UK has little experience in environmental taxes, and there is little extensive international experience to draw upon. The CCL should be seen as a somewhat experimental initiative, with adjustments necessary over the coming years to strengthen the financial incentives. This was the case with the energy taxes introduced in Scandinavia during the 1990s. ${ }^{97}$ The future of the CCL will also likely be shaped by EU level developments. Although the Commission has long abandoned plans for a carbon tax, it is continuing with a more pragmatic focus on energy products taxes based on extending the existing system of excise duties and a gradual increase in existing levels of taxation. ${ }^{98}$ Existing literature suggests that properly designed eco-taxes can encourage polluting companies to reduce their emissions and invest in cleaner technologies and fuels. ${ }^{99}$ Chanwai's research suggests that the effectiveness of incentive taxes depends partially on the existence of parallel reforms such as market restructuring to improve the supply of renewable energy fuels and provision of technical advice to companies interested in better managing their tax liabilities. The surveys disclosed that most energy management changes adopted by companies occurred before the Levy was introduced. The CCL experience suggests a much more mute, half-hearted and haphazard response than theory predicts. Apart from the give-ways available through 
the ECAs, evidence of companies 'physically' investing in cleaner machinery, as predicted by economic theory, remains to be widely seen.

The economic literature also stresses the importance of eco-taxes reflecting environmental externality costs (in this case global warming) if they are to have a substantial influence on polluters' behaviour. ${ }^{100}$ Unless there is a significant difference between the cost of brown and green energy, most industries are not going to make necessary radical changes in their operations towards sustainable energy systems. Quite simply, it must become more unprofitable to pollute and indulge in profligate energy consumption before widespread corporate changes can be expected. There is considerable scope for the Levy to be increased (but with corresponding NIC deductions or other concessions) given that over the past five years liberalisation of energy markets has resulted in major price reductions for British energy consumers. The academic literature also advocates ecological tax reform as providing a more holistic approach for addressing the inter-relationships between economic and environmental factors. The UK has made tentative steps towards ecological tax reform, first with the Landfill Tax and now with the CCL. Chanwai's research suggests that in relation to the Levy, the reform has been too tentative and the NIC reductions have not imparted a sufficiently tangible signal to companies to recruit extra staff whilst striving to reduce taxed energy use. A contributing factor to the muted effect of the NIC reduction is that many organisations reported maintaining separate payroll and energy cost accounting systems, thus impeding recognition of the inter-relationships between the two. Also relevant is that large, decentralised companies found it difficult to measure such financial changes. This suggests that eco-tax reform may unravel where reformers treat corporations as homogenous entities, and so fail to develop policies or mechanisms to ensure that the message of financial incentives can be effectively disseminated through large businesses. Reforms to integrate corporate environmental and financial reporting are one promising avenue by which the latter two problems could be addressed. ${ }^{101}$ 
The opportunity for certain energy-intensive industries to obtain high CCL rebates through participation in the CC Agreements also warrants review. Some industries surveyed felt unjustly excluded from the Agreements. To qualify for the rebates, an industry must be subject to the EU's IPPC Directive as incorporated in the Pollution Prevention and Control Act 1999. However, the IPPC regime was designed to control industrial pollution and only indirectly addresses the energy intensity of industry. It would appear that for primarily reasons of administrative convenience the government chose to use IPPC coverage to define eligibility to participate in the CC Agreements.

Another problematic feature of the CCL concerns the distribution of CCL revenues recycled between NIC reductions and subsidies for energy efficiency investments. Initially the government proposed a $0.5 \%$ NIC reduction coupled with a $£ 50$ fund to support energy efficiency investments, but this was later altered to a $0.3 \%$ NIC reduction and a $£ 150$ million fund in response to business lobbying. In 1999 , the House of Commons Environmental Audit Committee recommended doubling the amount of direct funding for energy efficiency under the CCL. ${ }^{102}$ There appears to be no substantive rationale for the basis of the current distribution, which should be carefully reviewed.

Apart from these 'fine-tuning' reforms, there are some very fundamental questions about the structure and scope of the CCL that warrant addressing. The CCL is essentially an industrial energy tax, rather than a carbon tax levied on the carbon content of fuels. Chanwai's research has revealed that energy suppliers' motivations to expand their supply of renewable energy has come mainly from the RO and not consumer pressure from CCL-taxed businesses. The RCEP favoured the CCL being in the form of an upstream (i.e. on energy suppliers) carbon-based tax to enable GHG emissions at source to be directly addressed, and it dismissed as overstated the administrative complexities of this option suggested by the Lord Marshall Report. ${ }^{103}$ The House of Commons Trade and Industry Committee was critical of the decision of the government to favour an energy over a carbon tax, which it saw motivated by 
a desire to protect the struggling coal industry which would be hurt most by a pure carbon tax ${ }^{104}$ There are advantages and disadvantages associated with each form of tax and whether a tax should be upstream or downstream (i.e. on consumers). The main argument for an energy tax on consumers over a carbon tax in that it should better promote energy efficient technologies. But an upstream carbon tax would involve fewer taxable entities than an energy consumption tax, and therefore less fiscal supervision and lower regulatory compliance costs. ${ }^{105}$ In an EU context, where Member States trade in electricity, there could be an advantage in adopting a carbon tax levied on refined fuel products at the point of consumption as such fuel excises make it easier to attribute tax revenues to the country of final sale. Of the tax schemes already adopted by European countries, none are pure carbon taxes. Denmark, Norway, and Sweden's taxes are assessed on the average carbon content of fuels with lower rates or exemptions for specific fuels or economic sectors. In Finland and the Netherlands, the tax is based on both carbon content and energy content. More detailed research into the relative advantages of carbon and energy taxation should be commissioned by UK authorities to assess better the arguments and existing experience.

There is also the contentious question of how high a carbon or energy tax should be pitched. The effectiveness of the CCL may have been undermined by significant declines of up to $40 \%$ in wholesale electricity prices since $1998 .{ }^{106}$ According to standard economic theory, the ideal carbon tax should be priced to achieve the economically optimal amount of GHG emissions at which the economic costs and benefits of reducing emissions by an extra tonne are equalised. But research also suggests there are huge uncertainties involved in modelling carbon taxes. ${ }^{107}$ Moreover, as global warming involves complex ethical issues and is plagued by considerable scientific uncertainty, determining an optimal level of GHG emissions (and hence climate change) for the purposes of eco-tax design is fraught with difficulty. Furthermore, research on the price elasticises of demand for energy suggest that such elasticises are low, implying that a very large energy tax is necessary to engender reductions in energy 
use. ${ }^{108}$ Yet, some eco-taxes may achieve highly elastic polluter responses; for example, the tax differential introduced between leaded and unleaded petrol in many countries including the UK was followed by rapid fuel substitution. ${ }^{109}$ Furthermore, a politically acceptable, small carbon tax could nonetheless change perceptions about the future, influencing investment strategies that determine long-term GHG emission trends.

\subsection{Emissions Trading and Taxing the Domestic and Transport Sectors}

The question of the relationship between the CCL and the pilot emissions trading scheme must also be eventually resolved. Should both operate concurrently, or should the UK opt for a single economic instrument to promote sustainable energy use? There is substantial economic literature devoted to arguing the relative merits of taxation versus marketable permits to control pollution. The essential difference is that whereas taxes set a 'price' on environmental use and rely on the market to effect corresponding behavioural changes towards the desired environmental goal, tradeable permits are based on government determining the environmental goal (in the form of an emissions 'cap') and relying on the market to price and allocate the tradeable entitlements. ${ }^{110}$ Whilst a tax instrument offers predictable costs (e.g. tax per unit of fuel), the resulting environmental performance can be uncertain; for example, the tax may be too low to encourage industries to reduce emissions. Alternatively, trading within a cap offers certainty of emission levels (i.e. the total number of tradeable pollution allowances equals the deemed sustainable pollution load), but the resulting compliance costs will vary by firm depending on a business's efficiency. These arguments have been considered by governments in relation to controlling GHG emissions, with some preference for a trading mechanism, partly because it would allow environmental groups to participate and withhold allowances. ${ }^{111}$

But a key weakness with tradeable permits is that they are not easily adapted to situations involving numerous, small polluters, such as motor vehicles and households. ${ }^{112}$ The market transaction costs are usually too high to integrate such smaller polluters in a trading scheme, which is better suited to a market of a 
few major, heavy polluters. Furthermore, a tax has the advantage that its revenues can fund compensation for low-income families or businesses vulnerable to higher energy prices and help finance development of low-emission technologies. Therefore, a combination of energy taxation and tradeable emission allowances may be most appropriate solution for the UK, with the CCL focusing on smaller polluters and tradeable emissions permits allocated to heavy industry.

Such a scenario would entail a major overhaul of the CCL regime. Arguably a major weakness with the CCL is the exemption to the polluting transport and household sectors. Some of the respondents interviewed in Chanwai's research saw the CCL as unfair because of this exemption. The European Commission earlier advised EU Member States that in responding to the Kyoto targets, governments should introduce policy measures that tackled all sectors, especially transport and households. ${ }^{113}$ Road transport dominates British emissions, although civil aircraft and shipping contribute increasingly. Whilst the UK appears on course to meet its Kyoto goal, this is only a modest start and does not reflect the very substantial GHG emission cuts needed to avoid dangerous climate change. The Levy in its current form will almost certainly not enable such long-term emission reductions. It may need to extend to petroleum products and be substantially increased, with CCL revenues from the private transport sector recycled into public transport investments. The recent company car tax reform is a positive initiative and is helping to encourage a switch to more fuel-efficient vehicles. ${ }^{114}$ As public tolerance of higher motoring charges is fragile, extending the CCL to private transport would require hypothecating the additional Levy revenues specifically for public transport improvements.

For the household sector, one challenge resides in building more energy efficient housing and renovating existing premises to incorporate heat and light saving measures. The government has introduced a package of soft incentive and regulatory measures in this area, but more work is needed. ${ }^{115}$ Households' share of UK final energy consumption is $29 \%$, second only to transport, and its 
quantity of energy consumption has ballooned by more than $25 \%$ since the early 1970s because of population growth and changing housing patterns. ${ }^{116}$ The RCEP has argued: 'the government is mistaken in keeping domestic fuel cheap for all households in order to help a minority of households who suffer from fuel poverty ... there should not ... be a blanket exemption for households from taxation measures aimed at limiting climate change'. ${ }^{117}$ The RCEP felt that the political and social objections to such a move could be overcome by careful recycling of Levy revenues to fuel poverty groups such as pensioners and the unemployed. Already, in 1994, the UK government ended VAT zero-rating on domestic energy, but eventually settled on a reduced VAT rate of $5 \%$. Ultimately, the CCL has a future role in Britain's GHG emission control efforts, but perhaps a role different to that envisaged by reformers. There is certainly scope to adjust technical features of the CCL regime, as our research has revealed. But beyond this, more serious reforms are needed. The role of emissions trading is one area. Extending the CCL to motorists and households is another. The danger, however, is that short-term political considerations will displace longer-term strategic thinking. The government's recent decision to bail out British Energy and talk of exempting nuclear power from the CCL reflects the continuing substantial political obstacles to effective environmental taxation reform in the UK. ${ }^{118}$ 


\section{Notes}

* Osgoode Hall Law School, York University, Toronto.

† MSC (Distinction) graduate, Department of Environmental and Geographical Sciences, Manchester Metropolitan University (MMU). I wish to acknowledge the assistance of Sustainability Northwest, Dr Paul Hooper at MMU and companies consulted during this research.

${ }^{1}$ Department of Environment, Food, Rural Affairs (DEFRA), The UK's Third National Communication Under the United Nations Framework Convention on Climate Change (DEFRA, 2001) at 18. In all, the UK's GHG emissions in 1990 were 208.4 million tonnes of $\mathrm{CO}_{2}$ equivalent (MtCe).

${ }^{2}$ Department of Environment, Transport and the Regions (DETR), Climate Change: The UK Programme (DETR, 2000).

3 DEFRA, supra $\mathrm{n} 1$ at 19.

${ }^{4}$ Ibid at 26.

${ }^{5}$ Royal Commission on Environmental Pollution, Energy: The Changing Climate, Cm 4749 (June 2000).

${ }^{6}$ See S. Barrett, 'Political Economy of the Kyoto Protocol', 14 Oxford Review of Economic Policy 4 (1998) at 20.

${ }^{7}$ Cabinet Office, The Energy Review (Performance and Innovation Unit, 2002) at 1.

${ }^{8}$ DEFRA, supra $\mathrm{n} 1$ at 1 .

${ }^{9}$ By way of introduction, see F. Muller, 'Mitigating Climate Change: The Case for Energy Taxes', 38 Environment 2 (1996) at 12.

${ }^{10}$ See J. Vehmas et al, 'Environmental Taxes on Fuels and Electricity: Some Experiences from the Nordic Countries' 27 Energy Policy (1998) at 343; A. Baranzini, J. Goldemberg and S.A. Speck, 'A Future for Carbon Taxes', 32 Ecological-Economics 3 (2000) at 395.

${ }^{11}$ European Commission, Proposal for a Council Directive Introducing a Taxon Carbon Dioxide Emissionsand Eneroy, COM(92) 226 final (1992). On trade competition issues, see R. Baron et al, Competitiveness Issues Related to Carbon/Energy Taxation (OECD, 1997).

12 J.A. Hoerner and F. Muller, Carbon Taxes for Climate Protection in a Competitive World (University of Maryland, 1996) at $11-12$

${ }^{13}$ US Department of the Treasury, 'Summaries of the Administration's Revenue Proposals Prepared by the Department of the Treasury: Draft as of 19 February 1993', reprinted in supplement of Highlights and Documents (Tax Analysts, 13.2.1993).

${ }^{14}$ Minister for Energy, P. Hodgson, 'Climate Change Policy: Early Decisions and Directions', Media Statement (30.8.2002). For other examples, see P. Layman, 'Eco-Taxes Stage Comeback in Europe', 77 Chemical E Engineering News 24 (1999) at 14

${ }^{15}$ See A. MacLachlan, 'French High Court Bars Eco-Tax Because Electricity is Clean', Nucleonics Week (4.1.2001) (partly because of the contribution of nuclear to the country's electricity).

${ }^{16}$ E. Mayo, 'The Potential of Eco-Taxes', 26 The Ecologist 5 (1996) at 204.

17 UK, This Common Inheritance: The Second Year Report, Cmnd 2086 (Stationery Office, 1992) at para 3.46.

${ }^{18}$ B.J. Richardson, 'Economic Instruments in UK Environmental Law Reform: Is the UK Government 'Sending the Right Signals'?', 3 European Journal of Law Reform 4 (2002) 427 at 436-8.

${ }^{19}$ DETR, A Better Quality of Life: A Strategy for Sustainable Development for the UK (DETR, 1999) at para 5.7.

${ }^{20}$ See e.g. Taxation and the Environment: Complementary Policies (OECD, 1993); A.L. Bovenberg and S. Cnossen, Public Economics and the Environment in an Imperfect World (Kluwer, 1995).

${ }^{21}$ See Environmental Taxes and Green Tax Reform (OECD, 1997); T.H. Tietenberg, Emissions Trading: An Exercise in Reforming Pollution Policy (Resources for the Future, 1985); D.A. Malueg, 'Emission Credit Trading and the Incentive to Adopt New Pollution Abatement Technology', 16 Journal of Environmental Economics and Management (1989) at 52 .

${ }^{22}$ See A. Pigou, The Economics of Welfare (Macmillan, 1932); R.H. Coase, 'The Problem of Social Cost', 3 Journal of Law and Economics 1 (1960).

${ }^{23}$ The Polluter Pays Principle: Definition, Analysis, Implementation (OECD, 1975).

${ }^{24}$ See M. Massarrat, 'Sustainability Through Cost Internalisation', 22 Ecological Economics 1 (1997) at 29.

${ }^{25}$ Article 174, Consolidated version of the Treaty establishing the European Community, OJ C 340, 10.11.1997.

${ }^{26}$ See P. Ekins, 'European Environmental Taxes and Charges: Recent Experience, Issues and Trends', Ecological Economics (1999) 31, 39; J.A. Hoerner and B. Bosquet, Environmental Tax Reform: The European Experience (Center for Sustainable Economy, 2000).

${ }^{27}$ See analysis of the European taxes in the Economic and Social Research Council, Economic Instruments and the Business Use of Energy: Response to the Consultation Paper: Government Task Force on the Industrial Use of Energy for the Global Environmental Change Programme (1998).

${ }^{28}$ The following discussion draws upon T.H. Tietenberg, 'Economic Instruments for Environmental Regulation', 6 Oxford Review of Economic Policy 1 (1990) at 17; S. Smith, 'Environmental and Public Finance Aspects of the Taxation of Energy', 14 Oxford Review of Economic Policy 4 (1998) at 64; T. Requate, 'Incentives to Innovate under Emission Taxes and Tradeable Permits', 14 European Journal of Political Economy 1 (1998) at 139.

${ }^{29}$ Environmentally Related Taxes in OECD Countries: Issues and Strategies (OECD, 2001) at 22-3.

${ }^{30}$ See D.H. Cole and P.Z. Grossman, 'When is Command-and-Control Efficient? Institutions, Technology and the Comparative Efficiency of Alternative Regulatory Regimes for Environmental Protection', 5 Wisconsin Law Review (1999) at 887.

${ }^{31}$ R. Stavins and B. Whitehead, 'Dealing with Pollution: Market-Based Incentives for Environmental Protection', 34 Environment 7 (1992) at 30. Such a conclusion, however, may fail to take into account regulatory requirements to use Best Available Technology (BAT).

${ }^{32}$ Smith, supra n 28 at 68 .

${ }^{33}$ See J.G. Backhaus, "The Law and Economics of Environmental Taxation: When Should the Eco-tax KickIn?', 19 International Review of Law and Economics 1 (1999) at 117.

${ }^{34}$ See Study on the Relationship Between Environmental/Energy Taxation and Employment Creation (European Commission, 2000); L.H. Goulder, Environmental Taxation and the 'Double Dividend': A Reader's Guide (National Bureau of Economic Research Working Paper No 4896, 1994).

${ }^{35}$ See L. Heinzerling, 'Selling Pollution, Forcing Democracy', 14 Stanford Environmental Law Journal (May 1995) at 300.

${ }^{36}$ G. Bándi, 'Financial Instruments in Environmental Protection' in G. Winter (ed), European Environmental 
Law: A Comparative Perspective (Dartmouth, 1996) 201 at 204.

37 OECD, supra n 29 at $91-3$.

38 Ibid at 27-8.

${ }^{39}$ See e.g. P. Ekins, 'The Impact of Carbon Taxation on the UK Economy', 22 Energy Policy 7 (1994) at 571.

40 OECD, supra n 29 at 29-30.

${ }^{41}$ M. Sagoff, 'Economic Theory and Environmental Law', 79 Michigan Law Review (1991) at 1393; see also

L. Tribe, 'Ways Not to Think About Plastic Trees: New Foundations for Environmental Law', 83 Yale Law Journal (1974) at 1315.

${ }^{42}$ See arguments of H. Daly, 'Allocation, Distribution and Scale: Towards an Economics that is Efficient, Just and Sustainable', 6 Ecological Economics (1992) at 185.

${ }^{43}$ See S. Felder and R. Schleiniger, 'Environmental Tax Reform: Efficiency and Political Feasibility', 42 Ecological Economics 1 (2002) at 107.

${ }^{44}$ Smith, supra n 28 at 72 .

45 N. Gunningham and P. Grabosky, Smart Regulation (Oxford University Press, 1998) at 14-15.

${ }^{46}$ House of Commons Debates, 17 March 1998, cc 1108-1109.

${ }^{47}$ Economic Instruments and the Business Use of Energy: A Report by Lord Marshall (HM Treasury, November 1998) at 16.

48 Ibid at 21 .

49 Ibid at 1.

${ }^{50}$ House of Commons Debates, 9 March 1999, c 181.

51 See S.A. Price, 'Environmental Taxation: The UK's Proposed Climate Change Levy', 12 Opinion (1999) at 335.

${ }^{52}$ B. Church, 'Climate Change Levy: Hot Air or Cold Comfort?', 29 Energy Policy 12 (2001) at 947; UK Steel Association, 'Concern that Tax Remains Major Drain on Manufacturing's Ability to Invest', press release (29 March 1999); Confederation of British Industry, 'Energy Tax Details Must Reflect Dangers to Manufacturing: CBI Chief', press release (22.4.1999).

${ }^{53}$ S. McGinness, G. Danby and A. Seely, The Climate Change Levy, Research Paper 99/93 (House of Commons, November 1999) at 10.

${ }^{54}$ Advisory Committee on Business and the Environment, Climate Change: A Strategic Issue for Business (DETR, 1998).

${ }^{55}$ On the consultation process, see e.g. HM Customs and Excise, Consultation on a Climate Change Levy (March 1999).

${ }^{56}$ See e.g. the reaction of Chemical Industries Association, News Release, 'CIA Welcomes Chancellor's PreBudget Energy Tax Statement' (9.11.1999).

57 See 'EU Backs Levy', 5 Energy and Environmental Management (May 2001).

${ }^{58}$ David Gee as cited in C. Hamilton et al, Ecological Tax Reform in Australia (Australia Institute, 1997 ) at 1.

59 See section 5.8 .

${ }^{60}$ European Commission, Environmental Taxes and Charges in the Single Market, COM(97) 9 final, clause 7.

${ }^{61}$ M. Rodi, 'Ecological Tax Reform in Germany', 54 Bulletin for International Fiscal Documentation 8/9 (2000) at 486.

${ }^{62}$ See German Federal Environment Ministry at www.bmu.de/english/fset800.htm.

${ }^{63}$ See Enhanced Capital Allowances Scheme at www.eca.gov.uk.

${ }^{64}$ The regulations were made pursuant to the Pollution Prevention and Control Act 1999 which implements in the UK the EU'S Integrated Pollution Prevention and Control Directive, 96/61/EC of 24.9.1996.

${ }^{65}$ For a full list of participants, see www.defra.gov.uk/environment/ccl/index.htm.

${ }^{66}$ See e.g. Schedule 2, Umbrella Climate Change Agreement for the Food And Drink Sector, March 2001.

67 DEFRA, supra $\mathrm{n} 1$ at 30 .

68 Cited in ibid.

69 R. Milne, 'Green Energy Target Problem', 17 Utility Week 20 (17.5.2002) at 13.

70 The Climate Change Levy: Impact on the UK Economy (Business Strategies, July 1999).

${ }^{71}$ See e.g. D. Howell, 'Climate of Fear', 13 Professional Engineering 17 (2000) at 38; 'Climate Levy Cost Rises', 127 Accountancy 1290 (2001) at 15.

${ }^{72}$ Church, supra n 52

${ }^{73}$ ECOTEC, Who Gains from the Climate Change Levy? (WWF-UK, September 1999).

${ }^{74}$ See e.g. P. Gander, 'Plastics Under Strain from Climate Levy', 77 Food Manufacture 4 (2002) at 18

${ }^{75}$ Business Strategies, supra n 70.

${ }^{76}$ One Year On: The Impact of the Climate Change Levy on Manufacturing SMEs (SGS Consulting, June 2002).

77 Ibid at $10-11$.

${ }^{78}$ The Climate Change Levy. Another Cost for Small Businesses (Federation of Small Businesses (FSB), July 2002).

${ }_{79}$ The thresholds are set out in the Finance Act 2000: definitions of exempt 'domestic use' in clause 9, Schedule 6 .

${ }^{80}$ FSB, supra $\mathrm{n} 78$ at 6.

${ }^{81}$ Ibid at 24

82 Ibid at 12

${ }^{83}$ Climate Change Levy Report (London Electricity, June 2002).

${ }^{84}$ J. Saddler, 'When the Levy Breaks', 242 Engineering 12 (2001) at 39.

${ }^{85}$ See UK Energy Efficiency Best Practice Programme at www.energyefficiency.gov.uk.

${ }^{86} \mathrm{~J}$. Kemp, 'Implementing Reduced Rate CCL: The Lessons', Energy and Environmental Management (November/ December 2001) at 9.

${ }^{87}$ The full study is detailed in K.L. Chanwai, Contribution of Economic Instruments to UK Environment Policy, with Reference to the Climate Change Levy and Business in Northwest England, MSc thesis (Manchester Metropolitan University, November 2002).

${ }^{88}$ For reasons, inter alia, of commercial confidentiality, no companies or organisations surveyed wished to be publicly identified.

${ }^{89}$ The RO initiative replaced the Non-Fossil Fuel Orders, introduced under the Electricity Act 1989, which failed to significantly stimulate the renewable energy sector: see J. Lipp, 'Policy Considerations for a Sprouting UK Green Electricity Market', 24 Renewable Energy (2001) at 31.

${ }^{90}$ The success rate of planning applications for renewable projects in England and Wales has to date been only about 26\%: House of Commons Environmental Audit Committee, A Sustainable Energy Strategy? Renewables 
and the PIU Report (House of Commons, 2002) at para 58.

91 'Mixed responses to NETA', Energy E Environmental Management (November/December 2001) at 7.

${ }^{92}$ Wholesale electricity price reductions for renewables have been significantly below that of other energy sources in the wake of the NETA: 'Relief for Green Generators' Energy and Environmental Management (January/ February 2002) at 10.

${ }_{93}$ Two hundred questionnaires were distributed, with a response rate of $20 \%$ within the requested deadline.

${ }^{94}$ See C. Parker, 'The Greenhouse Challenge: Trivial Pursuit?', 16 Environmental and Planning Law Journal 1 (1999) at 63.

${ }^{95}$ See J. Dine, The Governance of Corporate Groups (Cambridge University Press, 2000).

${ }_{96}^{96}$ Green Taxes: Rhetoric and Reality (Confederation of British Industry, April 2002).

97 See supra n 10.

${ }^{98}$ For recent developments, see R. Milne, 'Crunch Time for Unified Energy Tax Plan', 13 Utility Europe (July 2002).

${ }^{99}$ See R.B. Stewart, 'Economic Incentives for Environmental Protection: Opportunities and Obstacles' in R.L. Revesz, P. Sands and R.B. Stewart (eds), Environmental Law, The Economy and Sustainable Development (Cambridge University Press, 2000) at 171; C. Jeanrenaud, 'Economic Instruments for Environmental Policy' in C. Jeanrenaud (ed), Environmental Policy between Regulation and the Market (Springer Verlag, 1997) at 3.

${ }^{100}$ M. Massarrat, 'Sustainability Through Cost Internalisation: Theoretical Rudiments for the Analysis and Reform of Global Structures', 22 Ecological Economics 1 (1997) at 29.

${ }^{101}$ See generally D. Owen (ed), Green Reporting: Accountancy and the Challenge of the Nineties (Chapman and Hall, 1992); regarding UK reform proposals, see Company Law Review Steering Group, Modern Company Law for a Competitive Economy: Developing the Framework, Consultation document (Department of Trade and Industry, March $2000)$ at 181.

102 House of Commons Environmental Audit Committee, Energy Efficiency, HC 159-1 (22.7.1999).

${ }^{103}$ Energy: The Changing Climate, Cm 4749 (Royal Commission on Environmental Pollution, 2000) at 118.

${ }^{104}$ House of Commons Trade and Industry Committee, Impact on Industry of the Climate Change Leoy, HC 678-1 (House of Commons, 1999) at para 34.

${ }^{105}$ See A. Baranzini, J. Goldemberg and S.A. Speck, 'A Future for Carbon Taxes', 32 Ecological Economics 3 (2000) at 395.

106 A. Jameson, 'UK Electricity Market 'is Bust", The Times (Business) (10.10.2002) at 1.

${ }^{107}$ See T. Roughgarden and S.H. Schneider, 'Climate Change Policy: Quantifying Uncertainties for Damages and Optimal Carbon Taxes', 27 Energy Policy (1999) at 415.

108 See R.D. Duke and D.M. Kammen, 'The Economics of Energy Market Transformation Initiatives', 20 Energy Journal 4 (1999) at 15.

${ }^{109}$ P. Stoneman and G. Battisti, 'Fiscal Incentives to Consumer Innovation: The Use of Unleaded Petrol in Europe', 27 Research Policy 2 (1998) at 187.

${ }^{110}$ See C.W. Howe, 'Taxes Versus Tradable Discharge Permits: A Review in the Light of the US and European Experience', 4 Environmental and Resource Economics 2 (1994) at 1551; P. Koutstaal and A. Nentjes, 'Tradable Carbon Permits in Europe: Feasibility and Comparison with Taxes', 33 Journal of Common Market Studies 2 (1995) at 219 .

${ }^{111}$ See e.g. Role of Economic Instruments in Managing the Environment (Australian Industry Commission, 1997) at 69 .

${ }^{112}$ See Lessons from Existing Trading Systems for International Greenhouse Gas Emission Trading (OECD, 1998).

${ }^{113}$ European Commission, press release, 'Preparing for Implementation of the Kyoto Protocol' (19.5.1999) IP/99/333.

${ }^{114}$ Protecting the Environment:Reform of Company Car Taxation (Inland Revenue, 2000).

${ }^{115}$ For example, the Energy Efficiency Commitment, and the Home Energy Efficiency Scheme: see further DEFRA, supra $\mathrm{n} 1$ at 32

116 RCEP, supra $\mathrm{n} 103$ at 97.

117 Ibid at 119

118 See O. Morgan, 'The Prof's Power Play', The Observer (18.8.2002). 